食道再建用胃管の運動機能, 特に筋電図よりみた 幽門部輪状切開術の効果についての実験的研究

\begin{tabular}{llll}
\multicolumn{3}{c}{ 滋賀医科大学第 1 外科 } \\
梅原 & 秀樹 & 大同禮次郎 恵谷 敏 \\
谷奥 卓郎 & 岡本 寅司 &
\end{tabular}

\title{
EXPERIMENTAL STUDIES OF MOTOR FUNCTION OF SLIM GASTRIC TUBE FOR ESOPHAGOPLASTY, ELECTROMYOGRAPHIC ANALYSIS OF THE EFFECT OF ANNULAR MYOTOMIES AT PREPYLORIC REGION
}

\author{
Hideki UMEHARA, Rejiro DAIDO, Satoshi ETANI, Takuo TANIOKU \\ and Torashi OKAMOTO
}

Shiga University of Medical Science, School of Medicine, 1st Department of Surgery

\begin{abstract}
食道再建用大弯側胃管の延長と幽門ドレナージ効果を目的として, 幽門前庭部に嶈膜笳層輪状切開を付 加する方法を考案し, 雑種成犬を用い, 術直後より 3 カ月にわたり，筋電眓学的基礎的検討を加えた。す なわち筋電龱的には脱神経胃の胃体下部から幽門前庭部に括いては異所性の異常放電や逆䌮動性 BER が 高頻度に認められ，幽門部の収縮圧も高值を示したが，輪状切開を付加すると，切開より肛側の BER の 発生頻度は激減し，幽門部は電気的に静的な状態となり，その収縮圧も著明に低下する。また固形食とし てのレヂソペレットを用いた胃管よりの排出能は輪切炡よって促進される.

われわれの獎膜筋層輪状切開は幽門形成術として十分なドレナージ効果がえられることを実験的に証明 Lた.
\end{abstract}

索引用語 : 大弯側形成胃管, 幽門前庭部槳膜筋層輪状切開術, 觔電㘡, Basic elctric rhythm (BER)

\section{I はじめに}

経中心静脈高カロリー輸夜や成分栄養をはじめとした 術前術後の栄湌管理などの進歩とあいまって, 食道癌患 者の手術適応も拡大され，同時に手術成績の著しい向上 を見るようになった，食道の一期的切除後の胃による再 建術には，全胃を用いる場合と小弯側切離を行った大弯 側胃管を用る場合とがある。そして大弯側胃管を用いる

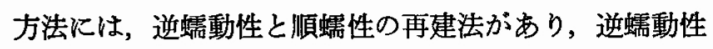
胃管としては, Beck \& Carrell (1905) がはじめて実験 的に行い, その後 Jianu (1912), Garviliu (1951) らの 研究に続き, Heimlich (1955) 飞よって確立され臨床 に応用されたようである゙。 また一方，順蠕動性胃管に 関しては, Mes (1948) と) とよってはじめて報告された が, 本邦でる内山文らが, 後綐隔順蠕動性胃管形成法と
して発表した.

われわれも，1973年より順蠕動性大弯側形成胃管によ る再建法を試みているが，全胃が良いか細い胃管が良い かは, その血行, 通過状態などより諸家により異論の多 いところである. しかし食道癌で比較的転移の多い小弯 側リンパ節群を小弯とともに広く切除した紐い胃管を使 用するわれわれの方法も合目的であると考觉る。細い胃 管の使用に当っては挙上胃管先端部の血行障害と幽門ド レナージのための Heineke-Mikulicz's pyloroplasty によ る胃管の短縮などが問題となる。そこで，幽門形成術の 代り飞胃前庭部墏膜筇層に $2 \sim 3$ 条の輪状切開 (以下輪 切)を加えて, 脱神経胃に和ける幽門部の異常收縮の防 止と胃管延長を兼ね，また一部の血管結禁による挙上胃 管先端部の血行改善法などを考案した.今回はとくに輪 
切によるドレナージの効果についての実験的成績を報告 する。

\section{II 実験方法}

$10 \mathrm{~kg} \sim 15 / \mathrm{kg}$ の 雑種成犬を用い, ウレタン $20 \mathrm{mg} / 15 \mathrm{~kg}$, $\alpha$-クロラローゼ20mg/kg の混合静脈麻醉下に開腹し，以 下のごときいるいろの外科的処置群を作製した後に，自 家製電極を胃獎膜面より刺入乙て筋電図を導出し，同時 に幽門引き抜き圧，幽門収縮圧をむ記録した。な各群 ともに術直後より 1 週間， 2 週間， 1 カ月， 3 カ月まで 検索した，電極には図 1 のごとく，市販つり針を用いて 双極電極とし，極間は $3 \mathrm{~mm}$ でその中間に接地電極を固 き 3 本のつり針が等間隔で並ぶように設計試作した，電 極の絶縁には，カシュー塗料を使用し，極間の抵抗は約 $30 \mathrm{~K} \Omega$ になるようにした。

図 1 極間は $3 \mathrm{~mm}$ で，中問に接地電極がくるよち に設計した。絶縁にはカシュー塗料を用いた。

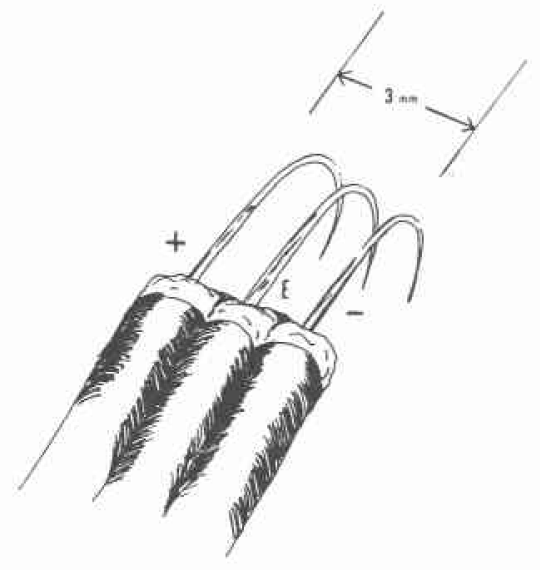

電極の装着部位は各実験群において幽門よりそれぞれ $1.0 \mathrm{~cm}, 3.0 \mathrm{~cm}, 10.0 \mathrm{~cm}$ の大弯側飞装着し, 特に縫合固 定などは行わなからた，さらに引抜き圧，収縮圧測定に はオープンチップ法の代りにすべてバルン法で行った。 バルンは太さ $8 \mathrm{~mm}$, 長さ $1.5 \mathrm{~cm}$, 内容 $1.0 \mathrm{ml}$ の円柱形の バルンを使用し，幽門よりなるべく遠くはなれた十二指 腸に切開を加兄，幽門輪を越えて胃前庭部まで挿入して 引き抜き圧および幽門部収縮圧を測定記録した。筋電図 導出は, 三栄測器製増幅器 Type $1205 \mathrm{C}$ を用い, 時定 数は0.1〜0.3秒を使用した. 压測定も同社製低圧用トラ ンスシューサー, 圧用増幅器 Type 1212 B を使用し, 筋電図，压ともにペン書オシロスコープで同時記録し た.
因 2 胃角部横切離. “印は, 双極電極 $1,2,3$ の 設置部位で，幽門上り $10 \mathrm{~cm}, 3 \mathrm{~cm}, 1 \mathrm{~cm}$ とした。 印は, 压用バルンン、 $\mathbf{a}$ は輪切付加前, $\mathrm{b}$ 的輪 切付加後

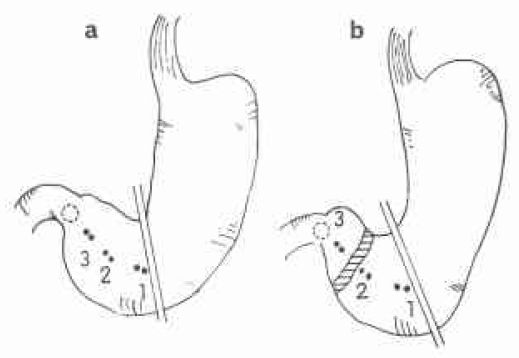

\section{1. 胃横切離群}

胃角部で周囲血管拉よび迷走神経を含めて図 2-a, b のごとく完全に胃を横切離し，肛側残胃の幽門前庭部筋 電図導出，幽門引き抜き圧測定を行った。測定後，幽門 より $1.5 \mathrm{~cm}, 2 \mathrm{~cm}$ 口側に, 胃の全周にわたり輪切を付加 し, 輪切後も前回同様の測定を行って比較検討した.

\section{2. 大弯側胃管群}

順蠕動性大弯側胃管の作成は, 図 3 -a, b の如く噴 門部直下で胃を切離し，幽門輪から小弯側へ $3.0 \mathrm{~cm} の$ 部位より大弯側幅約 $3.5 \mathrm{~cm}$ 残して小弯側切除を行なっ て，順蠴動性胃管を作成した。この胃管と噴門部口側断

図 3 大弯側胃管. ..印は, 電極 $1 ， 2 ， 3$ ， 印 は匟用バルーン，aは輪切無付加胃管，b海切 付加胃管
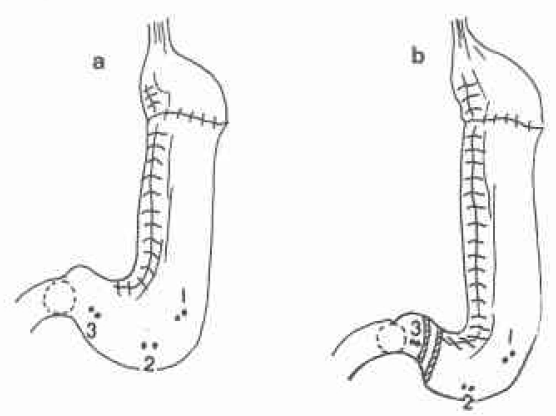

端と吻合し，胃管幽門前庭部汇輪切を加えた群と加えな い群とを, 術直後より術後 3 力月をで筋電図導出, 幽門 収縮圧などを測定して比較検討した。

3. 胃管よりの排出能

前述の大弯側胃管実験犬の術後 3 力月に括ける輸切無 付加胃管と, 輪切付加胃管の排出能を比較した.すなわ ち50 コの長さ $3 \mathrm{~mm}$, 直径 $1 \mathrm{~mm}$ の円筒状レ線不透過のレ 
ジンペレットを市販ドッグフード50g に混や゙て摂取せし め，両群について，掑取直後よりレ線透視下にレジンペ レットの排出状態を摂取後180分まで追求した.

\section{III 実験成槙}

正常犬では，胃平滑筋の電気的興奮をあらわす Basic electric rhythm (BER) は平均3.4/min であり，BERは 胃体上部より発生し，その電気的興奮は次第に末梢側へ 伝達されて幽門に終るといわれている．したがって正常 胃では，図4のごとく全胃にわたって逆蠕動性BER：異 常放電はほとんど認められず，BER の周期は規則正し く放電間隔の乱れなどはみられない。また幽門括約筋 は BER にわずかに遅れて収縮し，その収縮圧は平均 15 $\mathrm{cmH}_{2} \mathrm{O}$ であった.

図 4 正常胃笳電図㧍よび幽門収縮压

\section{雷体下部}

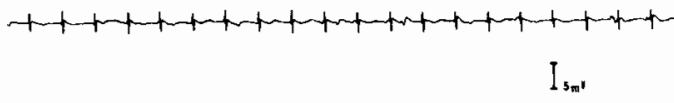

幽阿能磨部

$\longrightarrow 20 \mathrm{im}$

$1+1+1+1+1+1+1+1+1+1$

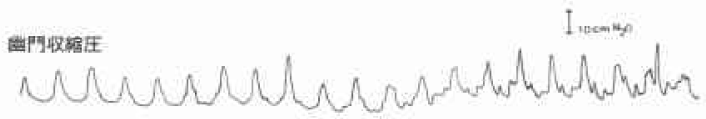

\section{1. 胃横切離群}

胃角部での横切離群では胃体上部にあるといわれてい るペースメーカーよりの筋性伝播が離断部で阻止され, さらに上位電気的中权よりの統合が乱れるために，図 5ーA のごとく正常では汪とんど認められない逆蝠動性 BER の発生が多く認められた。横切離した末梢側胃で の逆螦動性 BER は約 $30 \%$ 頻度で出現するが，この横 切離胃の前庭部に輪切を付加すると, 逆蠕動性 BER の 発生は抑制されて輪切より肛門側の BER，すなわち電 極 3 のそれは，図5-Bのごとく2.0/min となった。 た，輪切付加前後の幽門引き抜き 圧の変動は，図 6 の ごとく付加前では 平均 $25 \mathrm{cmH}_{2} \mathrm{O}$, 付加後平均 $15 \mathrm{cmH}_{2} \mathrm{O}$ と，輪切によって明らかな圧の低下が認められた。

2. 大弯側胃管群

輪切を付加しない大弯側胃管では，術直後より術後 3 カ月にいたるまで胃体部での BER の頻度はほとんど変 化しないが，胃体下部，幽門前庭部においてい異所性の 異常放電が多く時には逆蠕動性 BER が認められた。 BER の頻度は，術後 1 週間で平均 $3.9 / \mathrm{min}$ ，この時の異
図 $5 \mathrm{~A}$ 横切離胃筋電図, 電極 3 から 2 に向って逆 螾動性 BER が頻発している
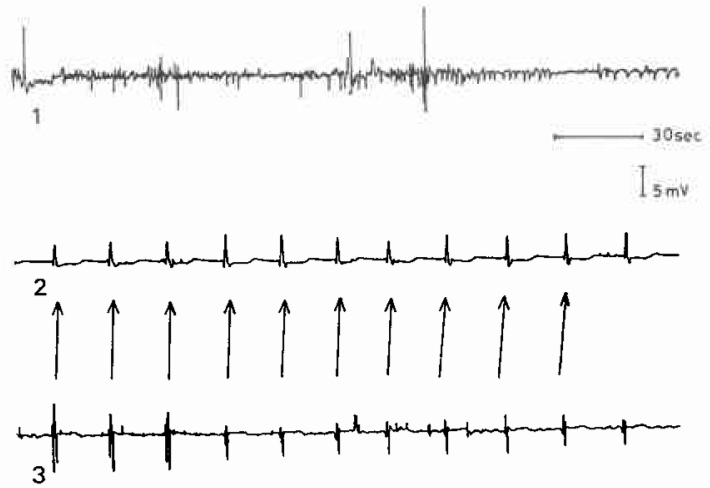

図 $5 \mathrm{~B}$ 図 $5 \mathrm{~A}$ の横切離罢に輪切を付加すると, 逆 蠕動性 BER は消失し, 電極 3 は電極 2 に比べ非 常に静的な状態になっている。

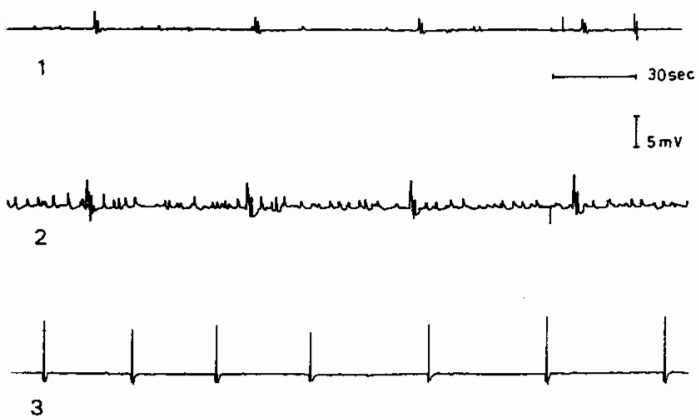

図 6 横切離胃幽門引き抜き圧

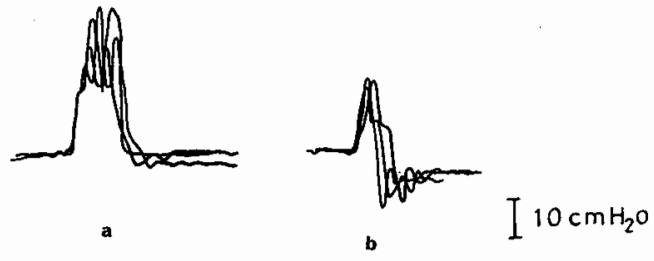

a. 輪切付加前 b. 輪切付加後

常放電の頻度は平均 $3.7 / \mathrm{min}$ ，最高 $13.4 / \mathrm{min}$ であった。 さらに筋電図を検討すると，輪切を付加しない術後 1 週 間の胃管では，図 7-A 黒丸印を中心に恰も電気的中心 が存在するごとく電極 2 に向っては逆蠕動性に, 電極 3 に向っては順蠕動性に BER が発生しているのが窥われ る.さらに術後 3 カ月の BER は図 7-B のごとく平均 $5.8 / \mathrm{min}$, 逆蠕動性 BER 28\%，異常放電1.6/min, であ った. BER の頻度は正常と比較して大差は認められな 
図 $7 \mathrm{~A}$ 輪切無付加贯管術後 1 週間では電極 2,3 の間に電気的中心がある如く, 電極 2,3 に向っ て逆蠕動性, 順蠕動性に BER が云達されている

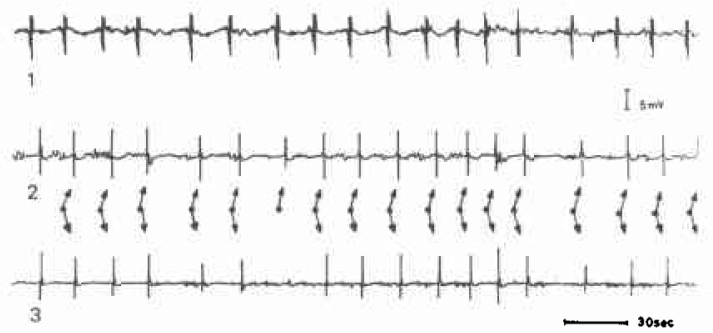

$\operatorname{liosm+2}_{2} \mathrm{O}$

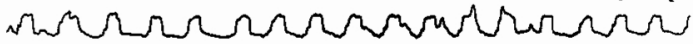

図 $7 \mathrm{~B}$ 術後 3 か月の輪切無付加胃管, 電極 3 から 1 下向って逆蝡動性 BER が多発している

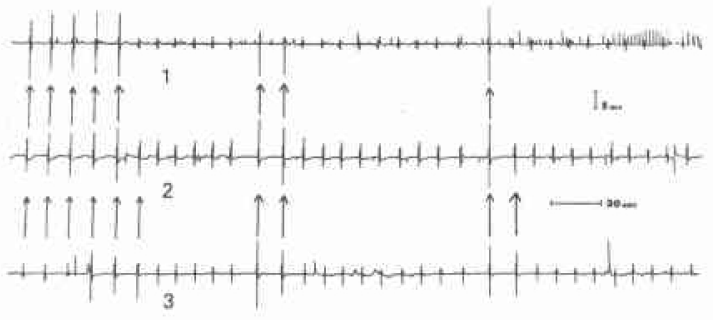

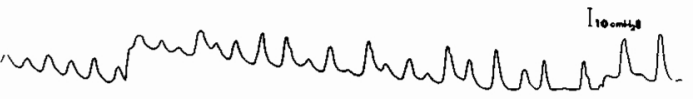

図 8 胃管輪切付加直後では, 図 7 A，Bでみられ た異常放電，逆蠕動作 BER はみられない。

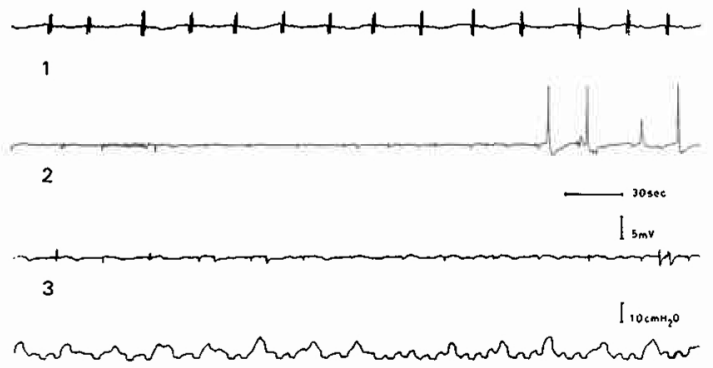

かったが，全経過にわたって異常放電，逆蝡動性 BER が高頻度に認められた。幽門部の収縮王は術後全測定 期間にわたって正常より高く, 術後 1 週間で平均 $22 \mathrm{~cm}$ $\mathrm{H}_{2} \mathrm{O} ， 3$ 力月経過してもなお平均 $20 \mathrm{cmH}_{2} \mathrm{O}$ であった。 ところが胃管前庭部に輪切を付加すると, 輪切付加直後 では図8のごとく電極 3 での BER の発生頻度は著しく
困 9 輪切付加胃管の術後 3 カ月で, 電極 3 は電極 2 に比べて BER の頻度は著しく少なく, 内王る 低い。

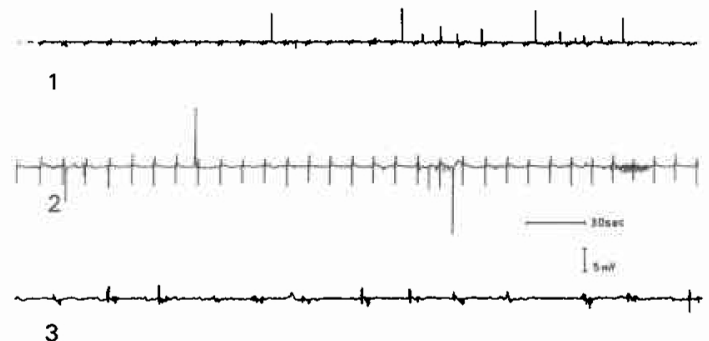

$10 \mathrm{cmm} \mathrm{z}^{\circ}$

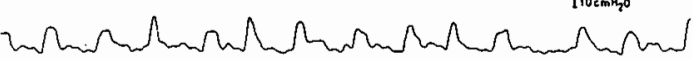

減少し, 電気的に静的な状態となって幽門部の運動がお こっていないことが窥われる. 同時に幽門の収縮圧す平 均 $8.4 \mathrm{cmH}_{2} \mathrm{O}$ と著明に低下した. すなわち輪切付加胃 管では術直後より 3 カ月にいたるまで, 輪切より口側の BER の発生頻度は輪切を佃加しない胃管と比べてる 差はなくその頻度は平均 $4.8 / \mathrm{min}$ であるが, 輪切より末 梢側の BER は術直後 $1.4 / \mathrm{min}$, 術後 1 週間 $1.7 / \mathrm{min}, 3$ カ月0.8/min と著しく減少した。これは口側からの BER が輪切によって完全に阻止されて肛門側へは全く伝播さ れていないことを示唆するもので，輪切より肛門側では 異常放電などほとんど認められず，また幽門収縮圧も， 図9のごとく全経過中5 $20 \mathrm{cmH}_{2} \mathrm{O}$ で平均 $12.5 \mathrm{cmH}_{2} \mathrm{O}$ であった. 筋電図上より BER の頻度と幽門圧を術後 1

表 1 輪切附加による BER と内圧の変動

\begin{tabular}{|c|c|c|c|c|c|c|c|c|}
\hline & \multicolumn{4}{|c|}{ 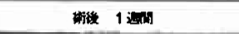 } & \multicolumn{4}{|c|}{ 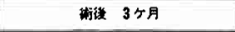 } \\
\hline & \multicolumn{3}{|c|}{ BRR: / win } & \multirow{2}{*}{$\begin{array}{c}\text { EF } \\
\mathrm{enH}_{2} \mathrm{O}\end{array}$} & \multicolumn{3}{|c|}{ BRR:/nin } & \multirow{2}{*}{$-\underset{\mathrm{cmH}_{2} \mathrm{O}}{\mathrm{E}}$} \\
\hline & 嗝, & $?$ & 3 & & 福 1 & 2 & 3 & \\
\hline 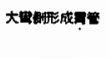 & 3.9 & $\begin{array}{l}3.9 \\
(3.7)\end{array}$ & $\begin{array}{r}3.9 \\
(3.0)\end{array}$ & 22 & $\begin{array}{l}5.8 \\
(1.0)\end{array}$ & $\begin{array}{c}5.8 \\
(1.0)\end{array}$ & $\begin{array}{r}5.8 \\
(1.0) \\
+28 \%\end{array}$ & 20 \\
\hline 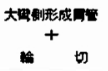 & 5.0 & 5.0 & 1.7 & 10 & 4.5 & 4.5 & 0.8 & 10 \\
\hline
\end{tabular}

週間と 3 カ月で, 輪切無付加群, 輪切付加群別に表示 すると，表 1 のごとく輪切によって幽門部の逆蠕動性 BER や異常放電が激減した．また輪切による創部の治 癒過程について術後 3 力月経過した摘出標本では, 輪切 の部分は肉眼的には㓔痕状となっているが，組織学的に は写高 1 のごとく筋組織の 再発生, 癒合など認められ ず，完全に筋層の連続性は断たれているのが認められ 
写真 1 矢印が輸切付加位置, 術後 3 か月

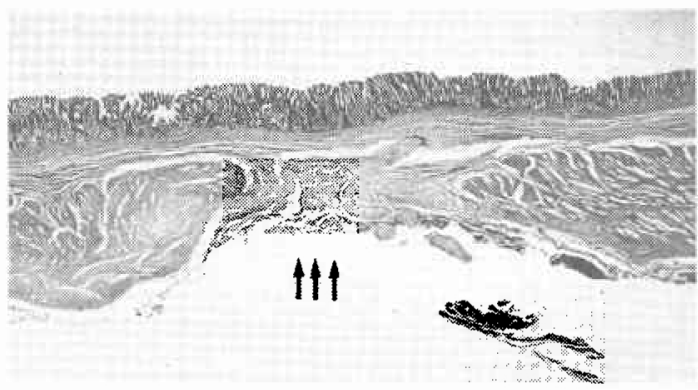

写真 2 a は輪切付加胃管, b は輪切無付加胃管

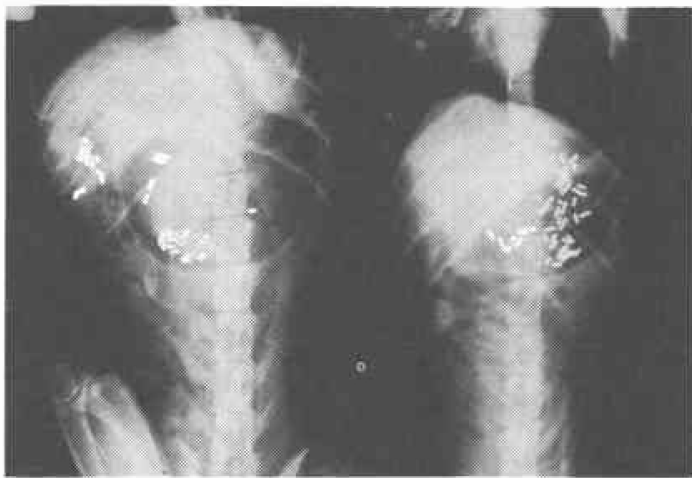

a

b

た。

\section{3. 胃管よりの排出能}

Radiopaque レジンペレットによる排出能の観察には, 術後 3 カ月の実験大を使用した。輪切付加群では，写真 2-a のごとく，㩒取後30分頃より少量ではあるが排出 されはじめ180分では，全体の40\%にあたるレジンペレ ットが十二指腸と小腸に排出された。しかしながら輪切 を付加しない群では，写真 2-b のごとく，180分経過 しても50個のレジンペレットは全く排出されていなかっ た.

\section{IV 考 察}

食道吻合はほかの消化管に比して不全発生率が高率で ある、したがって吻合部に余裕のある，かつ血行のよい 胃管を作製することが最も肝要であり，さらに術後は患 者が十分満足して 食事をしらる状態でなければならな w.

われわれも従来より幽門ドレナージには効果が確実 で，手術手技が簡便であるといら理由より HeinekeMikulicz 法を行ってきたが，挙上胃管に併用すると，
胃管が約 $2 \sim 3 \mathrm{~cm}$ 短縮する致命的な欠陥が生じてしばし ば踌躇することがあった．Heineke-Mikulicz 幽門形成 術の欠点を改善しょうといろいろの検討を重ねた結果, 胃管の延長が壳られ，幽門ドレナージ効果も十分な幽門 前庭部漿膜筋層輪状切開術を考案した。

一般に幽門部の収縮は，胃体上部あるいは噴門部付近 に存在する Pace-Maker から発生する徐波によって, 胃前庭部との協調運動として抗こるといわれているの で），幽門直前でとの筋組織を切断して協調運動をブロ ックすると幽門筋の収縮は抑制されるであるうと考兄 た. したがって迷走神経切断や, 近位胃切除, 小弯側切 除によって抢こる正常の胃平滑筋の電気的伝達現象の乱 れ，すなわち異常放電や这蠕動性 BER は幽門前庭部で の輪切で阻止される. 犬胃に利ける BER の発生頻度は， 岡田 ${ }^{9)}$ は約17秒に 1 回, 桑島 ${ }^{103}$ らは10.8sec $13.7 \mathrm{sec} に$ 1 回, Bass ${ }^{11)}$ は4.5cycles/min であると報告しているの で,われわれの平均 $3.4 / \mathrm{min}$ とほぼ同程度である。そし て正常犬胃では 平滑筋の電気的活動は非常に 安定して BER む規則正しく発生し，電気的活動の乱れむ容易に 規則正しい調律に復帰するのが常である。しかしながら 迷走神経切断や胃切離など，胃にいろいろの操作を加兄 た時には平滑筋群の規則正しい調律は乱れ，正常ではほ とんぞみられない異常放電, 逆蠕動が多く認められるよ らとなる．白鳥 ${ }^{12)}$ ，菅原 ${ }^{13)}$ らによると，胃体部，胃体上 部で胃を横切離しても末梢側胃の蠕動波には何ら影響は ないが，胃体部と幽門洞部の境界付近から末梢で胃を横 切離すると，正蠕動は次第に優勢を失い逆蠕動が優勢と なるが，幽門輪付近で横切離すると，正蠕動には何ら変 化をみないと述べている. 事実われわれる胃角部で横切 離し，その未梢側に打活る 3 力所の筋電図導出，幽門 引き拔き圧を検討したが，白鳥らと同様に，筋電図的 には逆蜻動が 頻発するし，幽門引き抜き圧る正常の 平 均 $15 \mathrm{cmH}_{2} \mathrm{O}$ に比して平均 $25 \mathrm{cmH}_{2} \mathrm{O}$ と著しく高值を示 すことを経験した。ついで横切離末梢側胃で幽門輪より $1.5 \mathrm{~cm}, 2.0 \mathrm{~cm}$ 口側に輪切を加えると, 口側の BER は この輪切で阻止される肛門側へは伝達されないばかり か，輪切より肛閏側での逆蝠動波の出現は皆無となり， さらに幽門引き抜き圧も輪切付加前に比べて著減した。 すなわら逆蜻動が頻発している胃角部横切離胃に輪切を 加えることは, 白鳥らのいら幽門輪付近での横切離に一 致するものと思われる。したがって幽門形成術として Heineke-Mikulicz 法が広く用いられているが，本法の 効果を十分らるためには幽門輪括約筋の綐切離のみなら 
ず，幽門前庭部への切り込みの長さが大きなポイントで ある ${ }^{14)}$ といわれている. 解剖学的に胃縦走笳は食道の続 きであり胃庭にて最も弱く, 胃小弯拉よび大弯で強く, さらに幽門に向って集合するので，幽門部で最強となっ て幽門括約筋を形成している. したがって幽門括約筋は それのみで機能しているのではなく，幽門前庭部筋群が 大きくその機能に関与しているものと考吾る゙．以上の ことからすればわれわれの幽門前庭部輪状切開法は幽門 機能の減弱乃至は, 機能の廃絶がえられ，幽門形成術之 しての効果も十分であろう.

つぎに，順蠕動性大弯側胃管に関する筋電図や幽門収 圧の検討で輪切を加兄ない胃管は, 術直後より術後 3 カ 月にいたるまで，胃管全体にわたって異常放電の頻発， 逆蝡動の発生がみられた. 生理的な発生頻度は全経過を 通して, 2.8 4.5/min であるが，異常放電は1.6〜13.4/ $\min$ と非常に高頻度であり, 幽門収縮圧も $15 \sim 45 \mathrm{cmH}_{2} \mathrm{O}$ と高值を示した。しかしながら, 胃管に輪切を付加した 群では, 輪切より口側の BER と異常放電の発生頻度に は無付加群と大盖はみられないが, 輪切より肛門側の BER の発生頻度は0.8〜 1.7/min と特に低值を示し, 口 側からの BER の伝達は輪切で阻止されて肛門側へは伝 播されない．また幽門の収縮圧も $5 \sim 17 \mathrm{cmH}_{2} \mathrm{O}$ と輪切 を付加しない胃管と 比べて 前回同様非常に 低值であっ た. 胃管や横切離末梢側胃では, 各筋組織が統合能力を 失って幽門部は Spastic な状態に陥っているが，罒門前 庭部に輪切を付加すると, 前述したごとく電気生理学的 に幽門部は弛緩して, 異常収縮や逆蠕動は発生しないも のと考光られる.

さらにわれわれの大弯側胃管の排出能について流動性 のバリウムを使用すると輪切の有無にかかわらず胃に流 入直後より十二指腸への排出が起こり，とくに両者間で は大差は認められなかった。しかしながらレジンペレッ トを用いた固形食の排出能では，両者間に著明な差を認 めた。すなわち, 術後 3 カ月の輪切無付加胃管では, レ シンンペレット摂取後180分経過しても排出しないのに反 し, 輪切付加胃管では, 摂取後30分頃より十二指晹に排 出されはじめ，180分後にはその $40 \%$ が十二指腸 および 空腸に排出されているのが認められた．Bruce ${ }^{15)}$ らは各 種迷切後の胃の排出能について, 流動物の排出には胃体 部が，固形物の排出には胃前庭部が大きく関与する。そ して, 固形物の排出が著しく悪いのは迷切による幽門前 庭部の協調運動の支障による結果であると述べている。 われわれの輪切無付加胃管に括いても，胃前庭部の協調
運動がいろいろの手術的処置で障害されていることが前 述の実験成績より判明したが，これに輪切を付加すると 前庭部と幽門との協調運動はみられないにしても，少な くとも電気的に逆震動や異常放電を狮制し，また幽門収 縮圧も減少させうるので，固形物の排出を容易にしてい るあのと考党る.

筋電図導出実験に，ネンブタール，ラボナールなどの 催眠，麻酔薬を使用した諸家の報告を散見することがあ るが，これらの麻醉薬は反射の抑制が強く，筋電図など の実験には適当ではないと考觉，わ秃われウレタン，

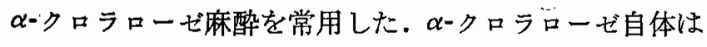
非常に弱い麻酔薬であるので，これにウレタンを追加し て混注すると，反射をそこなわずに適度な麻䣷深度がえ られる：また持続時間む長く長時間の実験に適している 16).なおウレタンの肝毒性が問題になるが，ウレタンの 毒性は遅発性であり, われわれが行っている期間では何 ら筋電図への影響は考兄られない。

\section{$\mathbf{V}$ 結 論}

1. 横切離胃末梢側には, 異常放電, 逆蠕動性 BER が頻発し，幽門引き抜き圧も高い。しかし，この末梢側 胃の幽門前庭部に墏膜筋層輪状切開を加えると, 輪切よ り肛側では異常放電, 逆螦動は消失し, 幽門の収縮圧も 著明に減少する。

2. 輪切無付加胃管では, 術直後より術後 3 力月にい たるまで，幽門前庭部に異常放電, 逆螦動性 BER が発 生し, 幽門の収縮圧す正常と比較すると著しく高い。一 方, 輪切付加胃管では, 全経過を通じて胃管上部より伝 播された BER は輪切によって完全ブロックされて, 輪 切より肛門側へは伝達されない。したがって輪切より肛 門側の BER の頻度は著しく低く, 異常放電もほとんど 認められず，幽門の収縮圧は輪切無付加群に比して半減 する.

3. 術後 3 カ月における胃管からの固形食の排出は, レジンペレット法では極めて不良であるが, 輪切付加に よって著しく好転する。

4. 大驾側胃管泟侖切を付加すると，胃管の延長は勿 論であるが，幽門部に括ける逆螦動性 BER の消失と幽 門収縮圧の著明な低下のために, 脱神経胃にみられる幽 門部の収縮は防止されて, 内容の通過が円滑であり, 実 験的にも食道再建用胃管としては合目的と考兄る。

なお, 本諭文の要旨は第12回消化器外科学会総会, 第 12 回消化器外科学会, 第 5 回国際消化器外科学会に発表 した。 


\section{文 献}

1) Heimlich, H.J., et al.: The use of a gastric tube to replace or by-pass the esophagus. Surg., 37: 549—559, 1955.

2) Mes, G.M.: New method of esophagoplasty. J. Internat. Coll. Surg., 11: 270-277, 1948.

3) 内山八郎：後䋛隔順蠕動性 胃管形成食道再建 術. 日胸会誌, 19：776-784, 1966 .

4) D.A.W. Edwards: Handbook of physiology, Alimental canal, Physiology of the gastroduodenal junction, 1985-2000, American physiological society, Washington, 1968.

5）岡林敏彦：胃横切離の幽門機能におよぼす影 響。日本平滑筋誌, 3:70-79, 1967.

6) 横路 洋: 各種迷切術之胃筋電図. 日本平滑筋 誌, $12: 15-24,1976$.

7) Nelson, T.S., et al.: Alteration in muscular and electrical activity of the stomach following vagotomy. Arch. Surg., 94: 821—835, 1967.

8) 田中直樹他：迷走神経の胃運動に及ぼす影響に 関する実験的研究. 日本平滑筋誌, 10：269一 285,1974 .

9) 岡田練之介 : 固の活動電位の発生部位と部位的
特唯に関する実験的研究. 日本平滑筋誌, 8： 99-111, 1972.

10) 桑島輝夫他：イヌの正常胃矨電図と収樎運動。 日本平滑筋誌, $12: 1-8,1976$.

11) Bass, P., et al.: Electrical activity of gastroduodenal junction. Am. J. Physiology, 201: 587-592, 1961.

12) 白鳥常男：消化器に拈ける筋電図，筋電図から みた胃の運動機能.日消会誌, 6：990-992, 1963.

13) Sugawara, K.: An electrographic study on the motility of canine stomach after transection and to end anastomosis. Tohoku J. Exp. Med., 84: 113-124, 1964.

14）白鳥常男：胃手術のすへて。幽門成形術，347一 364 , 金原出版, 1972.

15) Bruce G. Wilbur: Effect of proximal gastric, complete gastric and truncal vagotomy on gastric electric activity, motility and emptying. Ann. Surg., 178: 295-303, 1973.

16) 稲田 豊：動物実験と麻醉。呼吸と循罢，18： $31-34,1969$. 